\title{
Editorial
}

\section{Digital culture meets data: Critical perspectives.}

This special issue emerged from a need to explore how the turn to data is influencing work in digital culture and communication. Historically, digital culture is the focus of scholars positioned in a variety of disciplines research digital cultures, including media and communication studies, digital humanities, science and society studies and other critical theorists working at the intersections of social and cultural studies. The special issue ensued from the conference "Digital Culture meets data: Critical approaches" organized by the Digital Culture and Communication Section of the European Communication Research and Education Association (ECREA), at the University of Brighton in November 2017. With Ryan Burns and others in the organising committee we invited delegates to consider both theoretical and empirical perspectives that combine critical data studies and studies of digital culture. We posed a number of questions and provocations: What does this turn to data mean for our research, scholarship and pedagogic practice? How can new approaches to data be used to augment and diversify our research and educational approaches? But also, how might researchers challenge data paradigms or aim to show alternative or complementary ways to address digital culture and communication?

Since the conference took place in 2017, a lot of critical accounts have been written in relation to data, with focus on workplace practices and employment patterns (Moore 2017, Till 2018), but also activist and citizen practices (Jenzen et al 2020, Mendes et al 2019, Stephansen and Trere 2019, Milan 2019). Many of us have been particularly concerned with gender identities, gendered practices, including digital motherhood practices (Das 2019, Cobb 2020, Fotopoulou 2017, Jarrett 2019, Rich 2018, 2019; Thornham 2018). And there is a wealth of literature around digital health practices and platform infrastructures (Williams et al 2020, Lupton 2017), and what these mean for algorithmic persons (Kant 2020).

In the business world, digital culture is seen as the result of technological innovation. When bloggers write about it they refer to the ways in which digital technologies are shaping our everyday lives and the ways in which we interact with each other. Industry trends promote an open culture of transparency and collaborations, where social media groups, online forums, podcasts and blogs are all signs of a progressive digital culture (GDS 2020). In a blog with the title "What is digital culture?", Clayton d'Arnault equated digital culture with

"the Internet, transhumanism, Al, cyber ethics, security, privacy, and policy. It is hacking, social engineering, and modern psychology. More contextually, digital culture is using social media as our main mode of interaction with others; sharing every moment of your life on the internet; the selfie phenomenon; the live streaming obsession; the anonymity provided by online communities; Apple Pay and Android Pay; wearable technology; the use of emoji to enhance communication; internet/cell phone addiction; the sharing/on-demand economy; cloud computing and storage; the internet of things". 
This was in 2015. In 2020 this list more or less encompasses the phenomena that have been studied by scholars in the disciplines mentioned above.

For many researchers a shift of focus towards datafication seems not only inevitable, but also a necessity for the survival of research. In the introduction entitled "New Brave World", to "Datafied Society: Studying Culture through Data", Karin van Es and Mirko Tobias Schäfer (2017) pose epistemological questions about the future of the humanities. They argue in favour of incorporating methodological practices that involve the collection, processing and analysis of large datasets for understanding not only historical processes, but also "forms of social interaction and organization, political developments, and our understanding of democracy". These new forms of empiricism (Kitchin 2014) are indeed gaining weight in the humanities and social sciences, but they may come at the expense of inhabiting loci of critique. Arne Hintz, Lina Dencik and Karin Wahl-Jorgensen (2018) raised questions about how far processes of mass data collection stifle social dissent and opportunities for social change and mobilisation. Such processes may even appear to limit, rather than expand, the theoretical and methodological tools through which we increasingly try to understand mediation, the formation of identity, social life, politics and the creative industries.

Thinking about "what makes technology tick, why it's created, how it changes the way we live our lives, why it makes us behave the way we do, and what that means for our future" (d'Arnault 2015) is not only a stance in tech writing. As Vincent Miller (2020) suggests in the recent edition of his 2011 book "Understanding Digital Culture", technological determinism is rife among academics too. Linking identity formation or audience behaviours directly to the power of Instagram influencers, or to the use of technological innovations that have become everyday objects, such as Fitbit, are a common occurrence amongst students too. But culture and technology are in a dynamic relationship. For example, studies of digitization of cultural artefacts in museums have examined the values of access and visibility in certain cultural contexts, and have highlighted the digital as a cultural object and a cultural process (Geismar 2018). Secondly, technologies are not inevitable, despite certain cultural developments and social conditions (Mackenzie and Wajcman 1999), or the social values promoted by commercial platforms (van Dijck 2013). This issue is being published in the midst of developments towards a global contact tracing system that aims to inform about contact with someone diagnosed with Covid-19. The culture of crisis has given rise to a new set of solutions that appear politically inevitable - what has been called the "pandemic shock doctrine" (Klein 2020). These solutions are also technological; the pandemic has significantly impacted on people's attitudes to privacy and access to personal data, giving tech companies (led by tech giants such as Apple and Google) a green light to further develop inherently invasive practices (McGee and Murphy 2020). The development and wide use of such technologies are largely seen as necessities, a sign of the social determination of technology.

In this special issue, the dynamic relationship between data technologies and digital culture is highlighted. Authors are concerned with data technologies as sociotechnical systems and find intuitive ways to operationalize their critical analyses. 
Bias is a main theme investigated by authors here. Loes Bogers, Sabine Niederer, Federica Bardelli and Carlo De Gaetano (2020) examine algorithmic bias using pregnancy representations as a case study, while Andrea Rosales and Mireia Fernández-Ardèvol (2020) analyse ageism in platforms. In their article, Xerxes Minocher and Caelyn Randall (2020) argue that the racial bias that has historically informed police practices, particularly in certain areas in the United States, has become encoded in predictive policing systems. Two articles discuss methodological and epistemological issues in relation to doing research in digital culture with the use of big data. Gemma San Cornelio and Antonio Roig (2020) focus on mixed methods and underline the ambivalences, technicalities and practical experiences that inform their methodological choices. Maaike Bleeker, Nanna Verhoeff and Stefan Werning (2020) propose seeing data objects as knowledge objects and explore the different ways in which data sculptures, data based sonifications and other creative expressions that are based on data can contribute to sensory experiences of data.

Analysing Google search results and social media platforms, Bogers and colleagues (2020) found that pregnancy-related information is largely normative, and in fact in many cases biased. Building on this understanding, and using an intersectional approach, they discuss platform-specific vernaculars that represent pregnancy differently, and how these representations are co-constituted by user behavior and platform algorithms. Adding to discussions about methods, Bogers and colleagues (2020) introduce two visualization methods used in their comparative analysis: the image grid and the composite image.

Platform mechanisms are also the interest for Andrea Rosales and Mireia FernándezArdèvol (2020), who focus on age biases and ageist values, which become embedded in algorithms and design processes. The authors consider psychometric predictions on social networking sites, CAPTCHA security usability issues, biometrics in security systems such as face recognition, iris, retina and fingerprint scanning, and passive metering tools for smartphones. Through this analysis they show how cultural and social values that prioritise the needs of young people and disregard diversity shape data technologies. Both the articles by Bogers et al (2020) and by Rosales and Fernández-Ardèvol (2020) add to scholarly work that reflects on the dynamic relationship between culture and the production of data technologies, and the problematic ways in which racism, misogyny and heteronormativity can be reinforced through technology design (see Benjamin 2019, Buolamwini 2017, Hoffmann, 2019, Keyes, 2018, Noble 2018).

Using Milwaukee in Wisconsin as a case study, Minocher and Randall (2020) discuss how the technological imaginaries around predictive policing obscure the dangerous practices associated with the technology, especially when its use is linked to the surveillance of marginalized social groups, such as black and brown communities residing in certain geographical areas. As the authors stress these processes have real life consequences, such as decisions for placing children into care, or housing homeless people. Being framed as impartial and objective, sociotechnical systems of policing in fact have historical biases encoded within their operation. Minocher and Randall (2020) finally highlight the potential of developing social bonds and networks 
as forms of community resistance to big data surveillance and its sociotechnical networks of power.

Indeed, it is not enough to note how bias and discrimination can be perpetuated with the use of data technologies. Practices of resistance to the logics and processes of datafication are the topic of Sigrid Kannengießer's (2019) ethnographic study of CryptoParties - meetups for people interested in learning about encryption practices. Kannengießer (2019) discusses how the sense of solidarity and other social and community aspects aid the process of acquiring encryption skills in Cryptoparties. The study adds to a body of literature that shows how developing critical awareness of data surveillance and the mishaps of data infrastructures, and sharing knowledge while re-acting become vital means for empowerment in digital culture (see Bhargava 2015, Fotopoulou 2020, Grey et al 2018, Kannengießer and Kubitschko 2017).

Maaike Bleeker, Nanna Verhoeff and Stefan Werning (2020), in an epistemological paper about sensing data, are also concerned about knowledge making. They propose data objects as mediations of knowledge that help us experience data. Knowledge objects, such as soundscapes and sonifications, 3D materialisations, and data-driven interactive sites, are seen as relational and performative interfaces that activate different sensory modalities.

Addressing methodological question in relation to data and digital platforms, Gemma San Cornelio and Antonio Roig (2020) write about how they used a combination of methods in their Selfiestories project. Their mixed methods approach included ethnography and data scraping using the Instagram API, an approach which was principally adopted in response to technical and access issues faced when trying to extract data. Their paper discusses the methodological challenges that emerged and an evaluation of the mixed methods approach. Taking a narrative approach, they tell a story that uses both quantitative and rich ethnographic data, but note how visualizations were employed mainly to communicate research findings, rather than analyse data. San Cornelio and Roig raise an interesting proposal in relation to the notion of time and the ways in which it is articulated in social media.

Through these themes, the six papers of the Special Issue Digital Culture meets Data: Critical Perspectives showcase work from an international cohort of academics at various stages of their research career. Our authors have interpreted digital culture to encompass a wide range of social issues and critical questions beyond the fate of computational methods or the role of machine learning for the humanities and social sciences research. They explore data mechanisms and platforms as sociotechnical systems that are underpinned by cultural values, biases and historical discourses, but they also stress the opportunities for resistance. Digital culture and communication are changing, as infrastructures, media practices and social environments become progressively datafied. It is however important to remember that these processes are not inevitable, and to shape our scholarship, research and 
educational practices in ways that not only enable critical questions to emerge, but also reflect on how we may actually enable the transformations we claim to study.

\section{References}

Benjamin, R., 2019. Race After Technology: Abolitionist Tools for the New Jim Code. John Wiley \& Sons.

Bhargava, R., Deahl, E., Letouzé, E., Noonan, A., Sangokoya, D. \& Shoup, N. (2015). Beyond data literacy: reinventing community engagement and empowerment in the age of data. Data-Pop Alliance White Paper Series. Data-Pop Alliance (Harvard Humanitarian Initiative, MIT Lad and Overseas Development Institute) and Internews.

Bleeker, M., Verhoeff, N. and Werning, S., 2020. Sensing data: Encountering data sonifications, materializations, and interactives as knowledge objects. Convergence, p.1354856520938601.

Bogers, L., Niederer, S., Bardelli, F. and De Gaetano, C., 2020. Confronting bias in the online representation of pregnancy. Convergence, p.1354856520938606.

Buolamwini, J.A., 2017. Gender shades: intersectional phenotypic and demographic evaluation of face datasets and gender classifiers (Doctoral dissertation, Massachusetts Institute of Technology).

Clayton d'Arnault (2015) An introduction to Digital Culturist Oct 20, 2015 https://digitalculturist.com/what-is-digital-culture-5cbe91bfad1b

Charitsis, V., 2019. Survival of the (data) fit: Self-surveillance, corporate wellness, and the platformization of healthcare. Surveillance \& Society, 17(1/2), pp.139-144. Cobb, G., 2020. Negotiating Thinness Online: The Cultural Politics of Pro-anorexia. Routledge.

Cornelio, G.S. and Roig, A., 2020. Mixed methods on Instagram research: Methodological challenges in data analysis and visualization. Convergence, p.1354856520941613.

Das, R., 2019. Early Motherhood in Digital Societies: Ideals, Anxieties and Ties of the Perinatal. Routledge.

Fotopoulou, A., 2017. From Egg Donation to Fertility Apps: Feminist Knowledge Production and Reproductive Rights. In Feminist Activism and Digital Networks (pp. 91-121). Palgrave Macmillan, London.

Fotopoulou, A., 2018. From Networked to Quantified Self: Self-Tracking and the Moral Economy of Data Sharing. In A networked self and platforms, stories, connections (pp. 144-159). Routledge.

GDS (2020). Insights Industry outlooks and trends. What is Digital Culture? Everything You Need to Know. https://gdsgroup.com/insights/technology/what-isdigital-culture.

Geismar, H., 2018. Museum object lessons for the digital age (p. 164). UCL Press. Gray, J., Gerlitz, C., \& Bounegru, L. (2018). Data infrastructure literacy. Big Data \& Society. https://doi.org/10.1177/2053951718786316.

Hintz, A., Dencik, L. and Wahl-Jorgensen, K., 2018. Digital citizenship in a datafied society. John Wiley \& Sons. 
Hoffmann, A.L., 2019. Where fairness fails: data, algorithms, and the limits of antidiscrimination discourse. Information, Communication \& Society, 22(7), pp.900915.

Horst, H.A. and Miller, D. eds., 2020. Digital anthropology. Routledge.

Jenzen, O., Erhart, I., Eslen-Ziya, H., Korkut, U. and McGarry, A., 2020. The symbol of social media in contemporary protest: Twitter and the Gezi Park movement. Convergence, p.1354856520933747.

Kannengießer, S., 2019. Reflecting and acting on datafication-CryptoParties as an example of re-active data activism. Convergence, p.1354856519893357.

Kannengießer, S, Kubitschko, S (2017) Editorial. Acting on media: influencing, shaping and (re)configuring the fabric of everyday life. Media and Communication 5(3): 1-4.

Kant, T., 2020. Making it Personal: Algorithmic Personalization, Identity, and Everyday Life. Oxford University Press, USA.

Keyes, O., 2018. The misgendering machines: Trans/ $\mathrm{HCl}$ implications of automatic gender recognition. Proceedings of the ACM on Human-Computer

Interaction, 2(CSCW), pp.1-22.

Klein, N. (2020) Big Tech's Pandemic Shock Doctrine, The Nation. 16 July 2020. https://www.youtube.com/watch?v=17XWaLV6C8c

McGee, P. and Murphy, H. (2020) Coronavirus apps: the risk of slipping into a surveillance state. April 28, 2020 https://www.ft.com/content/d2609e26-887511ea-a01c-a28a3e3fbd33

Mendes, K., Ringrose, J. and Keller, J., 2019. Digital feminist activism: Girls and women fight back against rape culture. Oxford University Press.

Miller, V., 2020. Understanding digital culture. SAGE Publications Limited.

Milan, S., 2019. Acting on data (fication). Citizen Media and Practice: Currents, Connections, Challenges, pp.212-226.

Minocher, X. and Randall, C., 2020. Predictable policing: New technology, old bias, and future resistance in big data surveillance. Convergence, p.1354856520933838. Moore, P.V., 2017. The quantified self in precarity: Work, technology and what counts. Routledge.

Noble, S.U., 2018. Algorithms of oppression: How search engines reinforce racism. nyu Press.

Rich, E., 2018. Gender, health and physical activity in the digital age: between postfeminism and pedagogical possibilities. Sport, Education and Society, 23(8), pp.736-747.

Rich, E., 2019. Making Gender and Motherhood Through Pedagogies of Digital Health and Fitness Consumption:'Soon It Made Us More Active as a Family'. In Digital Dilemmas (pp. 205-223). Palgrave Macmillan, Cham.

Rosales, A. and Fernández-Ardèvol, M., 2020. Ageism in the era of digital platforms. Convergence, p.1354856520930905.

Stephansen, H.C. and Treré, E. eds., 2019. Citizen media and practice: Currents, connections, challenges. Routledge.

Till, C., 2018. Self-tracking as the mobilisation of the social for capital accumulation. In Self-Tracking (pp. 77-91). Palgrave Macmillan, Cham.

Thornham, H., 2018. Gender and Digital Culture: Between Irreconcilability and the Datalogical. Routledge. 
Van Es, K. and Schäfer, M.T., 2017. The datafied society. Studying culture through data. Amsterdam University Press.

Williams, R., Will, C., Weiner, K. and Henwood, F., 2020. Navigating standards, encouraging interconnections: Infrastructuring digital health platforms. Information, Communication \& Society, 23(8), pp.1170-1186. 